\title{
Prevalence of the main infectious causes of abortion in dairy cattle in Algeria
}

\author{
Salima-Yamina Derdour ${ }^{1}$, Fella Hafsi ${ }^{1}$, Naouelle Azzag ${ }^{1}$, Safia Tennah ${ }^{1}$, \\ Abdelouahab Laamari ${ }^{1}$, Bernard China ${ }^{2}$, Farida Ghalmi ${ }^{1}$ \\ ${ }^{1}$ Research Laboratory Management of Local Animal Resources, Higher National Veterinary School, \\ El Alia, Oued Smar, 1615 Algiers, Algeria \\ ${ }^{2}$ Scientific Institute for Public Health, 1050, Brussels, Belgium \\ fghalmi@yahoo.fr
}

Received: April 21, $2017 \quad$ Accepted: August 11, 2017

\begin{abstract}
Introduction: Abortion in cattle is a major source of economic losses for the agriculture sector. It can be due to infectious or non-infectious factors. Among infectious factors, parasites, bacteria, viruses, and fungi can be involved. The present work investigated the prevalence of the main infectious agents of abortion in Algerian cattle. Material and Methods: Altogether 278 non-aborting and 82 aborting cows were analysed. Results: The prevalence ranged from $0 \%$ for Tritrichomonas foetus to $15 \%$ for Neospora caninum. Additionally, a case-control study was performed to find the association between the presence of the pathogens and the occurrence of abortion in cows. The odds ratios were significant for Neospora caninum, bovine herpes virus 4 , BVD virus, Brucella abortus, Salmonella Dublin, Leptospira interrogans serovar Hardjo, and Coxiella burnetii. Conclusions: The pathogens enumerated here could be major causes of abortion among Algerian cattle.
\end{abstract}

Keywords: cows, abortion, infectious agents, Algeria.

\section{Introduction}

Abortion remains one of the most important health problems for the dairy industry. Indeed, reproductive failure due to abortion is a critical issue in cattle farming because of economic losses and public health implications. The causes of abortion are numerous: infectious agents (bacteria, viruses, protozoa, and fungi), toxic agents, heat stress, and genetic abnormalities $(7,22)$.

The infectious causes are the most frequent but their aetiological agents are not always identified (7). The most common viruses involved are bovine viral diarrhoea virus (BVDV) (25), bovine herpes virus 4 (BoHV4) (11), bovine herpes virus 1 (BoHV1) (35), and more recently the Schmallenberg virus (31). The bacteria most frequently noted are Brucella abortus (30), Chlamydophila abortus (23), Coxiella burnetii (2), Leptospira interrogans serovar Hardjo (here referred to as L. Hardjo) (33), Salmonella enterica serovar Dublin (here referred to as $S$. Dublin) (28), Campylobacter foetus subsp. Venerealis (37), and Listeria monocytogenes (39). Neospora caninum (6) and Tritrichomonas foetus (16) are the parasites most recurrently associated with abortion. Among fungi, Aspergillus sp. has been involved in abortions in cows (24). Establishing a definitive cause of foetal loss can be difficult due to the absence of pathognomonic lesions, lack of available confirmatory tests for certain conditions, and time between expulsion and examination of foetal tissues (7). Furthermore, it is often difficult to determine if one of these agents is the cause of abortion since they can also be found in the reproductive tract of healthy cows. Usually infectious causes can be associated with sporadic as well as epidemic abortions, often without clinical signs other than abortion (12). The identification of abortion causes is essential for developing rational herd health programmes that will reduce losses due to abortion. Effective control measures require not only prompt and accurate diagnosis of abortion but also understanding of the multiple factors involved in this affliction. Only little information is available about the situation regarding cattle abortion in Algeria and the role of abortions resulting from infection in reproductive failure. 
The purpose of this study was to investigate an epidemiological and prospective approach to the diagnosis of the most common infectious causes of bovine abortion. The investigation was carried out by comparing data from aborting and non-aborting cows with respect either to the presence of antibodies against $N$. caninum, BVDV, BoHV1, BoHV4, L. Hardjo, B. abortus, or C. burnetii, or to the presence of DNA of $S$. Dublin and T. foetus.

\section{Material and Methods}

This study was conducted in Algiers County $\left(36^{\circ} 46^{\prime} \mathrm{N} 3^{\circ} 13^{\prime} \mathrm{E}\right)$, an area with an important dairy industry husbanding large herds of cows. A total of 54 farms were randomly selected. On the basis of an epidemiological questionnaire, the farms were classified as controls if no abortion had occurred in the previous five years and as cases if abortion events had occurred in this timeframe. Based on this criterion, 15 establishments were treated as case farms and 39 as control farms. In general, 360 cows were analysed, comprising 278 cows without recent abortion events (control cows) and 82 cows with them (case cows). The age of the cows ranged from 1 to 11 years.

Blood samples were collected from the tail vein into a $10 \mathrm{~mL}$ dry tube. After coagulation, the tubes were centrifuged $(2,700 \mathrm{~g}$ for $10 \mathrm{~min})$. The sera were collected and stored at $-20^{\circ} \mathrm{C}$ until analysis. Serological testing against BoHV1, BoHV4, and BVDV was performed by multiplex ELISA using a commercial kit (BIO-X Abortion ELISA Kit, Bio-X Diagnostics, Belgium). The detection of antibodies against $N$. caninum was performed also using a commercial kit (BIO K 192 - Monoscreen AbELISA Neospora caninum (SRS2) indirect, Bio-X). This test had previously been validated (18). For the detection of $B$. abortus antibodies, the rose bengal test was applied and a commercial kit served again (RSA-RB, ID, France). The positive samples were confirmed by complement fixation assay (29) using a commercial reagent (Brucellosis antigen for the complement fixation test, IDvet). For $L$. Hardjo, C. burnetii, and C. abortus antibodies, commercial ELISA kits were relied upon here also (Priocheck L. Hardjo Ab, Prionics, the Netherlands; IDEXX Q Fever Ab Test and IDEXX Chlamydiosis Total Ab Test, Idexx, France).

Faeces were collected directly by rectal sampling. For Salmonella isolation, $1 \mathrm{~g}$ of faeces was added to $10 \mathrm{~mL}$ of Rappaport-Vassiliadis medium (Rappaport-Vassiliadis Broth CM0669, Oxoid, France). The tubes were incubated at $42^{\circ} \mathrm{C}$ for $24 \mathrm{~h}$. One millilitre of positive culture was centrifuged at $10,000 \mathrm{~g}$ for $3 \mathrm{~min}$. Next, the pellets were suspended in $50 \mu \mathrm{L}$ of sterile pure water and boiled for $10 \mathrm{~min}$. The tubes were then centrifuged and the supernatant was transferred into a clean tube and conserved at $-20^{\circ} \mathrm{C}$ until analysis. The presence of Salmonella Dublin was determined by PCR as previously described (40).

For the isolation of $T$. foetus, mucus and vaginal washing fluids were used. Vaginal mucus was collected with a long pipette fitted to a syringe. Aliquots of $1 \mathrm{~mL}$ of the samples were used for in vitro cultivation in Diamond's medium (Remel, USA). The DNA extraction and the PCR were performed as previously described (16). The percentages were compared using the Chi-square test. The association between the presence of a pathogen and the occurrence of abortion was assessed using odds ratios (Medcalc Statistical Software, South Korea).

\section{Results}

The prevalence of different pathogens was analysed in 360 cows (Table 1) and was found to range from $0 \%(T$. foetus $)$ to $15 \%$ ( $N$. caninum $)$. Out of the 360 cows, $80(22.2 \%)$ were positive for at least one of the tested pathogens: 55 cows were positive for only one pathogen and 25 were positive for two or three pathogens (Table 2). Among the positive cows, $44(15.82 \%)$ were control cows and $36(43.90 \%)$ were case cows. To study the relationship between contact with a pathogen and abortion, a case-control study was conducted (Table 3). The odds ratio was statistically significant $(\mathrm{P}<0.05)$ for $N$. caninum, BoHV4, BVDV, S. Dublin, L. Hardjo, and C. burnetii. Therefore, for these pathogens, the odds ratio was significantly higher than 1 , indicating an association between cow contact with the pathogens and occurrence of abortion. From the odds ratio calculation, two fractions can be calculated, these being the attributable fraction in the exposed cases (EAF) and the attributable risk in population (PAF) (Table 3) (43). The former is the expected percentage of reduction in the number of cases following elimination of the exposure in exposed cases, and the latter is the expected percentage of reduction in the number of cases following elimination of the exposure in the population. Finally, the Bayesian probability of occurrence of abortion if the cow was positive for the pathogen was also calculated. These computations indicated that the most important risk of abortion in exposed cows is due to contact with BVDV and $S$. Dublin (93\%), L. Hardjo (89.4\%), BoHV4 (88.2\%), C. burnetii (85.9\%), B. abortus (76.8\%), and $N$. caninum $(60.9 \%)$. The conditional probability of abortion in the presence of the pathogen ranged from 0 (BoHV1 and C. abortus) to 0.76 (L. Hardjo). 
Table 1. Prevalence of the different studied abortive pathogens

\begin{tabular}{lllll}
\hline Pathogen & Positive & Negative & Prevalence (\%) & CI 95\% \\
\hline N. caninum & 54 & 306 & 15.00 & $11.31-18.69$ \\
BoHV1 & 2 & 358 & 0.55 & $0-1.31$ \\
BoHV4 & 13 & 347 & 3.61 & $1.68-5.54$ \\
BVD virus & 5 & 355 & 1.39 & $0.18-2.6$ \\
B. abortus & 11 & 349 & 3.06 & $1.28-4.84$ \\
S. Dublin & 5 & 355 & 1.39 & $0.18-2.6$ \\
L. Hardjo & 14 & 346 & 3.89 & $1.89-5.89$ \\
C. burnetii & 6 & 354 & 1.67 & $0.35-2.99$ \\
C. abortus & 3 & 357 & 0.83 & $0-1.77$ \\
T. foetus & 0 & 360 & 0.00 & ND \\
\hline At least one pathogen & 80 & 280 & 22.22 & $17.9-26.5$ \\
\hline ND - not determined & & & &
\end{tabular}

Table 2. Cows presenting multiple infections

\begin{tabular}{|c|c|c|c|c|c|c|c|c|c|c|c|}
\hline Cow & case & $\mathrm{NC}$ & BoHV1 & BoHV4 & BVD & BA & SD & LI & $\mathrm{CA}$ & $\mathrm{CB}$ & Total \\
\hline 1 & No & 1 & 0 & 0 & 1 & 1 & 0 & 0 & 0 & 0 & 3 \\
\hline 2 & Yes & 1 & 0 & 0 & 1 & 1 & 0 & 0 & 0 & 0 & 3 \\
\hline 3 & Yes & 1 & 0 & 1 & 0 & 0 & 1 & 0 & 0 & 0 & 3 \\
\hline 4 & Yes & 1 & 0 & 1 & 0 & 0 & 0 & 1 & 0 & 0 & 3 \\
\hline 5 & Yes & 1 & 0 & 1 & 0 & 1 & 0 & 0 & 0 & 0 & 3 \\
\hline 6 & Yes & 0 & 0 & 0 & 1 & 0 & 0 & 1 & 0 & 1 & 3 \\
\hline 7 & Yes & 0 & 0 & 0 & 0 & 1 & 0 & 1 & 0 & 1 & 3 \\
\hline 8 & Yes & 0 & 0 & 0 & 1 & 0 & 1 & 1 & 0 & 0 & 3 \\
\hline 9 & No & 1 & 0 & 0 & 0 & 0 & 0 & 1 & 0 & 0 & 2 \\
\hline 10 & No & 1 & 0 & 0 & 0 & 0 & 0 & 1 & 0 & 0 & 2 \\
\hline 11 & No & 1 & 0 & 0 & 0 & 0 & 0 & 1 & 0 & 0 & 2 \\
\hline 12 & No & 1 & 0 & 0 & 0 & 0 & 0 & 1 & 0 & 0 & 2 \\
\hline 13 & No & 1 & 0 & 1 & 0 & 0 & 0 & 0 & 0 & 0 & 2 \\
\hline 14 & No & 1 & 0 & 1 & 0 & 0 & 0 & 0 & 0 & 0 & 2 \\
\hline 15 & Yes & 1 & 0 & 1 & 0 & 0 & 0 & 0 & 0 & 0 & 2 \\
\hline 16 & No & 1 & 1 & 0 & 0 & 0 & 0 & 0 & 0 & 0 & 2 \\
\hline 17 & No & 1 & 0 & 0 & 0 & 1 & 0 & 0 & 0 & 0 & 2 \\
\hline 18 & Yes & 1 & 0 & 0 & 0 & 0 & 0 & 0 & 0 & 1 & 2 \\
\hline 19 & yes & 1 & 0 & 0 & 1 & 0 & 0 & 0 & 0 & 0 & 2 \\
\hline 20 & No & 0 & 0 & 0 & 0 & 1 & 0 & 0 & 1 & 0 & 2 \\
\hline 21 & No & 0 & 0 & 0 & 0 & 1 & 1 & 0 & 0 & 0 & 2 \\
\hline 22 & No & 0 & 0 & 1 & 0 & 0 & 0 & 0 & 1 & 0 & 2 \\
\hline 23 & Yes & 0 & 0 & 1 & 0 & 1 & 0 & 0 & 0 & 0 & 2 \\
\hline 24 & Yes & 0 & 0 & 0 & 0 & 1 & 0 & 1 & 0 & 0 & 2 \\
\hline 25 & Yes & 0 & 0 & 1 & 0 & 0 & 1 & 0 & 0 & 0 & 2 \\
\hline Total & & 16 & 1 & 9 & 5 & 9 & 4 & 9 & 2 & 3 & 58 \\
\hline
\end{tabular}

NC - Neospora caninum ; BA - Brucella abortus ; SD - Salmonella Dublin ; LI - Leptospira interrogans ; CA - Chlamydophila abortus; $\mathrm{CB}$ - Coxiella burnetii 
Table 3. Analysis of the relation between contact with a pathogen and the abortion in cows: a case-control study

\begin{tabular}{|c|c|c|c|c|c|c|c|c|c|c|c|}
\hline Pathogen & Status & + & - & Total & Exposition rate & OR & CI $95 \%$ & $\mathrm{p}$ & EAF & PAF & $\mathrm{P}(\mathrm{A} / \mathrm{P})$ \\
\hline \multirow{2}{*}{ N. caninum } & case & 21 & 61 & 82 & $25.6 \%$ & \multirow{2}{*}{2.56} & \multirow{2}{*}{$1.38-4.73$} & \multirow{2}{*}{$<0.01$} & \multirow{2}{*}{$60.9 \%$} & \multirow{2}{*}{$15.6 \%$} & \multirow{2}{*}{0.39} \\
\hline & control & 33 & 245 & 278 & $11.9 \%$ & & & & & & \\
\hline \multirow{2}{*}{ BoHV1 } & case & 0 & 82 & 82 & $0.0 \%$ & \multirow{2}{*}{$0.67 *$} & \multirow{2}{*}{$0.03-14.1$} & \multirow{2}{*}{0.8} & \multirow{2}{*}{ ND } & \multirow{2}{*}{ ND } & \multirow{2}{*}{0.0} \\
\hline & control & 2 & 276 & 278 & $0.7 \%$ & & & & & & \\
\hline \multirow{2}{*}{ BoHV4 } & case & 9 & 73 & 82 & $11.0 \%$ & \multirow{2}{*}{8.45} & \multirow{2}{*}{$2.53-28.2$} & \multirow{2}{*}{$<0.01$} & \multirow{2}{*}{$88.2 \%$} & \multirow{2}{*}{$9.7 \%$} & \multirow{2}{*}{0.69} \\
\hline & control & 4 & 274 & 278 & $1.4 \%$ & & & & & & \\
\hline \multirow{2}{*}{ BVD } & case & 4 & 78 & 82 & $4.9 \%$ & \multirow{2}{*}{14.21} & \multirow{2}{*}{$1.57-128.93$} & \multirow{2}{*}{$<0.05$} & \multirow{2}{*}{$93.0 \%$} & \multirow{2}{*}{$4.5 \%$} & \multirow{2}{*}{0.8} \\
\hline & control & 1 & 277 & 278 & $0.4 \%$ & & & & & & \\
\hline \multirow{2}{*}{ B. abortus } & case & 6 & 76 & 82 & $7.3 \%$ & \multirow{2}{*}{4.31} & \multirow{2}{*}{$1.28-14.51$} & \multirow{2}{*}{$<0.05$} & \multirow{2}{*}{$76.8 \%$} & & \\
\hline & control & 5 & 273 & 278 & $1.8 \%$ & & & & & $5.0 \%$ & 0.55 \\
\hline & case & 4 & 78 & 82 & $4.9 \%$ & & & & & & \\
\hline$S$. Dublin & control & 1 & 277 & 278 & $0.4 \%$ & 14.21 & $1.57-128.93$ & $<0.05$ & $93.0 \%$ & $4.5 \%$ & 0.7 \\
\hline$I$ Hardis & case & 10 & 72 & 82 & $12.2 \%$ & 044 & $288 \quad 3000$ & $<001$ & 8040 & $0.8 \%$ & 076 \\
\hline & control & 4 & 272 & 278 & $1.4 \%$ & ז & $2.00-50.80$ & -0.01 & (1) & 10.070 & 0.10 \\
\hline C abortus & case & 0 & 82 & 82 & $0.0 \%$ & $048 *$ & 33 & 063 & & & \\
\hline C. avortas & control & 3 & 275 & 278 & $1.1 \%$ & $0.48^{\circ}$ & $0.02-9.33$ & 0.03 & ND & ND & 0.0 \\
\hline & case & 4 & 78 & 82 & $4.9 \%$ & 708 & $127-3936$ & $<005$ & $850 \%$ & $42 \%$ & 0.67 \\
\hline C. burnetul & control & 2 & 276 & 278 & $0.7 \%$ & 1.08 & $1.21-39.30$ & $<0.05$ & 05.970 & 4.270 & 0.01 \\
\hline At least one & case & 36 & 46 & 82 & $43.9 \%$ & 4.16 & $242-7.16$ & $<001$ & $76 \%$ & $33.4 \%$ & 0.45 \\
\hline pathogen & control & 44 & 234 & 278 & $15.8 \%$ & 7.00 & 2.721 .10 & -0.01 & 1070 & 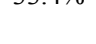 & 0.70 \\
\hline
\end{tabular}

*: The OR normally has an infinite value due to the presence of 0 negative samples in case farms. In this case, we added 0.5 at each value. Exposed attributable fraction $=\mathrm{EAF}=(\mathrm{OR}-1) / \mathrm{OR}$

Population attributable fraction $=\mathrm{PAF}=\mathrm{Po}(\mathrm{OR}-1) /(1+(\mathrm{Po}(\mathrm{OR}-1))$

$\mathrm{Po}=$ number of exposed in controls/number of controls

$\mathrm{P}(\mathrm{A} / \mathrm{P})=$ probability of abortion $(\mathrm{A})$ if pathogen $(\mathrm{P})=\mathrm{p}(\mathrm{A} \cap \mathrm{P}) / \mathrm{P}(\mathrm{P})$

$\mathrm{ND}$ - not determined

\section{Discussion}

Abortion in cows remains a major concern in dairy farms, with potentially significant economic losses. The identification of the abortion causes could lessen the impact of this pathology. These causes can be divided into infectious and non-infectious ones. Even if infectious causes seem to be the most prevalent, the identification of the pathogen involved is difficult due to the facts that different pathogens can be involved in the same case and that diagnosis methods are not always optimised. Moreover, diagnosis is not always made quickly on aborted foetuses, and delay allows tissue alteration and contamination (7). This work focused on the infectious causes, which can consist of parasites, fungi, bacteria, or viruses.

No T. foetus positive Algerian cows were detected by PCR, in opposition to, among others, a Brazilian study where the same methodology was used and which showed a prevalence of $33.4 \%$ of infected cows (14). N. caninum is considered a major cause of abortion in cattle worldwide (6). A previous study in Algeria indicated that the $N$. caninum seroprevalence in cattle was $19.6 \%$ using IFAT (19). On the other hand, ELISA gave fewer positive results than IFAT (20). Therefore, our results were consistent with the previous ones. Nevertheless, a similar study on 221 cows from 25 farms was recently performed in Algeria's western neighbour, Morocco (26). The prevalence of $N$. caninum in this study was $8.52 \%$ (CI 95\%: $4.4 \%$ $12.6 \%)$, which is significantly lower $(\mathrm{P}<0.05)$ than in our study (CI 95\%: 11.3\%-18.7\%). N. caninum is a major cause of abortion in Algeria as previously described (19). This study confirmed the previous data with a calculated OR of 2.56. In New Zealand, $N$. caninum was also associated with abortion $(\mathrm{OR}=3.36)$ and the attributable risk in population was $3.0 \%$, which means that only $3 \%$ of the abortions in cows are due to $N$. caninum (32). In our study, the population attributable fraction was $15.6 \%$, indicating that the risk of abortion due to $N$. caninum is higher in Algeria. Among 54 positive cows, 16 (29.6\%) had also been in contact with at least one other pathogen. Among these 16 cows, only $6(37.5 \%)$ had already aborted (case cow). In fact, the local cow breed (Atlas Brown) is widely infected with $N$. caninum without 
a significant abortion effect (19). Therefore, it is not abnormal to find seropositive cows without abortion. It is underlined by the attributable exposed risk of $60.9 \%$. Contact with $N$. caninum will not lead to systematic abortion. In Algeria, it is mainly linked to the breed (19).

B. abortus infection is a notifiable zoonosis. The Algerian authorities organise an inspection every six months and slaughter the positive animals. For this reason, the observed seroprevalence is rather low $(3.06 \%)$. B. abortus was shown to be associated with abortion in Algerian cattle with an OR of 4.31, significantly higher than 1 . Nevertheless, a previous study on Algerian cattle indicated a prevalence of $26.3 \%$ in cattle flocks using the rose bengal technique (3), but in this study no link with abortion was demonstrated. Therefore, the difference was related to the sampled region being different or to a reduction of the prevalence in the last 10 years due to the drastic control measures ordained by the authorities. By comparison the observed prevalence was $33.5 \%$ in Morocco (26), 14\% in Uganda (27), and 5.1\% and $6.3 \%$ in Pakistan $(1,5)$. The rose bengal test is not a very specific test and false positives can occur. Therefore, a confirmation test is required (17). For $S$. Dublin, the PCR allowed the serovar Dublin to be distinguished from the other Salmonella serovars (41). The observed prevalence was $1.39 \%$. $S$. Dublin is a major concern in Northern Europe (Denmark and Sweden) and is kept under careful surveillance (4). There, the prevalence was estimated both by immunoassays on bulk milk or sera and by faeces culture and PCR. The prevalence was lower when determined by culture and PCR than by serology (28). For faecal cultures examined by PCR the prevalence was below 1\% (28). Nevertheless, in Algeria, S. Dublin was significantly associated with abortion in cows $(\mathrm{OR}=14.21)$ and the conditional proportion of abortion if $S$. Dublin was present was 0.7 . Therefore, even with a low prevalence, the risk of abortion is high. For L. Hardjo, the observed prevalence was low $(3.89 \%)$ in comparison with the prevalence observed in Morocco (9.09\%) (26). Despite the low prevalence a significant association was observed with abortion in Algerian cattle $(\mathrm{OR}=9.65)$ and another such significant association $(\mathrm{OR}=1.84)$ was also found in New Zealand (32). This indicated that this pathogen can also be considered a potential cause of abortion in cows. For $C$. burnetii, the seroprevalence observed in Algerian cattle was $1.67 \%$. This is lower than the seroprevalence of $12.3 \%$ obtained from cow sera in Spain (9). In China, seropositive cattle (381/1140, $33 \%$ ) were detected in 13 of 15 surveyed provinces and in 16 of 19 herds (84\%) (15). There is, however, a significant association in Algeria between the presence of antibodies against $C$. burnetii and abortion in cows $(\mathrm{OR}=7.08)$, and the conditional abortion probability attributable to being in contact with $C$. burnetii was 0.67. The reduction of cases in the population by eradication of $C$. burnetii would nonetheless be only $4.2 \%$, due to this low prevalence.

C. abortus was considered a rare cause of abortion in cattle. The prevalence in Algerian cattle was $0.83 \%$. It is significantly lower than the prevalence observed in Jordan (19.9\%) (35), but similar to the prevalence observed in Sweden (0.4\%) (21). In Algerian cows, C. abortus was not considered to be associated with abortion since the three positive cows were controls.

Regarding BVDV infection, our prevalence was $1.39 \%$, which was surprisingly low. Indeed, in Morocco, the prevalence for BVDV was significantly higher $(\mathrm{P}<0.05)$ with 37.71\% (CI 95\%: 23.1\%$52.4 \%$ ) (26). But the Algerian prevalence was comparable to the European, ranging from $0.6 \%$ in Ireland to $1.4 \%$ in Denmark (10). On the other hand, BVDV is a major concern also in industrial countries such as Australia with around $80 \%$ of flocks infected (25). Nevertheless, the presence of specific antibodies against BVDV was clearly associated with abortion in our study $(\mathrm{OR}=14.21)$ and the attributable risk in the exposed population was $93 \%$, indicating that the risk of abortion from contact with BVDV was high. But since the prevalence is low, the attributable risk in the population was low $(4.5 \%)$ and the prevention of BVDV infection would not drastically reduce the number of abortions in Algerian cows. By comparison, in New Zealand, a significant association between exposure to BVDV and abortion was found, with an OR of 2.01 and a population attributable risk of $3.5 \%$ (32). BoHV1, the agent of infectious bovine rhinotracheitis (IBR), was associated with abortion in cows in different countries but not in Algeria since the two cows detected as positive were control cows. The seroprevalence was only $0.55 \%$, contrasting, for example, with the $28.78 \%$ rate observed in Turkey (8). The seroprevalence of BoHV4 was 3.61\% in Algerian cows. Data from Turkey indicated a percentage of $41.3 \%$ (8) and data from Morocco 9.52\% (26). BoHV4 has been described as a cause of abortion in cows in Belgium with an OR of 1.81 (13). This association seems to be stronger in Algeria with an OR of 8.45 . The population attributable fraction was $9.7 \%$, indicating that the eradication of BoHV4 in the cattle population could reduce the abortion rate by $10 \%$.

To summarise, in Algerian cattle, the observed prevalence ranking was $N$. caninum (15.0\%) > L. Hardjo $(3.89 \%)>$ BoHV4 $(3.61 \%)>$ B. abortus $(3.06 \%)>C$. burnetii $(1.67 \%)>S$. Dublin and BVDV $(1.39 \%)>C$. abortus $(0.83 \%)>\operatorname{BoHV} 1(0.55 \%)>$ T. foetus (0\%). In China, the prevalence was BoHV1 $(36.3 \%)>N$. caninum $(31.3 \%)>\operatorname{BVDV}(7.5 \%)>$ B. abortus $(6.2 \%)>$ C. abortus $(5 \%)>$ Toxoplasma gondii (1.3\%) (38), and in Morocco, BoHV1 (50\%) > BVDV $(37.71 \%)>$ B. abortus $(33.48 \%)>$ Leptospira $(9.09 \%)>N$. caninum $(8.52 \%)(26)$. This indicates that the prevalence is different as a function of the sampling and of the sampled region. 
Prevention is one of the most powerful approaches to reducing the impact of pathogens in cattle abortion. The attributable fraction in the population indicated that the expected reduction of abortion in the population by eradication of the studied pathogens is $41.4 \%$. In the population, it is the elimination of $N$. caninum that can reduce the number of abortions the most $(15.6 \%)$. But it indicates also that most of the abortions are due either to uninvestigated pathogens or to non-infectious causes.

Conflict of Interests Statement: The authors declare that there is no conflict of interests regarding the publication of this article.

Financial Disclosure Statement: This work was supported by a grant of the Algerian Ministry of Higher Education and Scientific Research: Project PNR 20112013 "Diagnostic et epidémiosurveillance des avortements d'origine infectieuse chez la vache dans la région d'Alger".

Animal Rights Statements: None required.

Acknowledgements: The authors thank Professor B. Losson from the University of Liège (Belgium) for providing some technical support in this study.

\section{References}

1. Abubakar M., Javed Arshed M., Hussain M., Ehtisham-ul-Haq Ali Q.: Serological evidence of Brucella abortus prevalence in Punjab province, Pakistan - a cross-sectional study. Transbound Emerg Dis 2010, 57, 443-447.

2. Agerholm J.S.: Coxiella burnetii associated reproductive disorders in domestic animals - a critical review. Acta Vet Scand 2013, 55, 13-23.

3. Aggad H., Boukraa L.: Prevalence of bovine and human brucellosis in western Algeria: comparison of screening tests. East Mediterr Health J 2006, 12, 119-128.

4. Agren E.C., Sternberg Lewerin S., Wahlström H., Emanuelson U., Frössling J.: Low prevalence of Salmonella in Swedish dairy herds highlight differences between serotypes. Prev Vet Med 2016, 125, 38-45.

5. Ali S., Akhter S., Neubauer H., Melzer F., Khan I., Abatih E.N., El-Adawy H., Irfan M., Muhammad A., Akbar M.W., Umar S., Ali Q., Iqbal M.N., Mahmood A., Ahmed H.: Seroprevalence and risk factors associated with bovine brucellosis in the Potohar Plateau, Pakistan. BMC Res Notes 2017, 10, 73-83.

6. Almería S., López-Gatius F.: Bovine neosporosis: clinical and practical aspects. Res Vet Sci 2013, 95, 303-309.

7. Anderson M.L.: Infectious causes of bovine abortion during midto late-gestation. Theriogenology 2007, 68, 474-486.

8. Aslan M.E., Azkur A.K., Gazyagci S.: Epidemiology and genetic characterization of BVDV, BHV-1, BHV-4, BHV-5 and Brucella spp. infections in cattle in Turkey. J Vet Med Sci 2015, 77, 1371-1377.

9. Astobiza I., Ruiz-Fons F., Piñero A., Barandika J.F., Hurtado A., García-Pérez A.L.: Estimation of Coxiella burnetii prevalence in dairy cattle in intensive systems by serological and molecular analyses of bulk-tank milk samples. J Dairy Sci 2012, 95, 1632-1638.
10. Barrett D.J., More S.J., Graham D.A., O'Flaherty J., Doherty M.L., Gunn H.M.: Considerations on BVD eradication for the Irish livestock industry. Irish Vet J 2011, 64, 12-21.

11. Chastant-Maillard S.: Impact of bovine herpes virus 4 (BoHV-4) on reproduction. Transbound Emerg Dis 2015, 62, 245-251.

12. Clothier K., Anderson M.: Evaluation of bovine abortion cases and tissue suitability for identification of infectious agents in California diagnostic laboratory cases from 2007 to 2012. Theriogenology 2016, 85, 933-938.

13. Czaplicki G., Thiry E.: An association exists between bovine herpesvirus-4 seropositivity and abortion in cows. Prev Vet Med 1998, 33, 235-240

14. De Oliveira J.M., Da Silva G.M., Batista Filho A.F., De Melo Borges J., De Oliveira P.R., Brandespim D.F., Mota R.A., Pinheiro J.W. Jr.: Prevalence and risk factors associated with bovine genital campylobacteriosis and bovine trichomonosis in the state of Pernambuco, Brazil. Trop Anim Health Prod 2015, 47, 549-555.

15. El-Mahallawy H.S., Kelly P., Zhang J., Yang Y., Zhang H., Wei L., Mao Y., Yang Z., Zhang Z., Fan W., Wang C.: High seroprevalence of Coxiella burnetii in dairy cattle in China. Trop Anim Health Prod 2016, 48, 423-426.

16. Felleisen R.S., Lambelet N., Bachmann P., Nicolet J., Müller N., Gottstein B.: Detection of Tritrichomonas foetus by PCR and DNA enzyme immunoassay based on rRNA gene unit sequences. J Clin Microbiol 1998, 36, 513-519.

17. Getachew T., Getachew G., Sintayehu G., Getenet M., Fasil A.: Bayesian estimation of sensitivity and specificity of rose bengal, complement fixation, and indirect ELISA tests for the diagnosis of bovine brucellosis in Ethiopia. Vet Med Int 2016, Article ID 8032753, (http://dx.doi.org/10.1155/2016/8032753).

18. Ghalmi F., China B., Kaidi R., Losson B.: Evaluation of a SRS2 sandwich commercial enzyme-linked immunosorbent assay for the detection of anti-Neospora caninum antibodies in bovine and canine sera. J Vet Diagn Invest 2009, 21, 108-111.

19. Ghalmi F., China B., Kaidi R., Losson B.: Neospora caninum is associated with abortion in Algerian cattle. J Parasitol 2011, 97, 1121-1124.

20. Ghalmi F., China B., Jenkins M., Azzag N., Losson B. Comparison of different serological methods to detect antibodies specific to Neospora caninum in bovine and canine sera. J Vet Diagn Invest 2014, 26, 136-140.

21. Godin A.C., Björkman C., Englund S., Johansson K.E., Niskanen R., Alenius S.: Investigation of Chlamydophila spp. in dairy cows with reproductive disorders. Acta Vet Scand 2008, 50,39 .

22. Hovingh E.: Abortions in dairy cattle-I common causes of abortions. Virginia Cooperat Exten 2009, 404-288.

23. Kaltenboeck B., Hehnen H.R., Vaglenov A.: Bovine Chlamydophila spp. infection: do we underestimate the impact on fertility? Vet Res Commun 2005, 29, 1-15.

24. Knudtson W.U., Kirkbride C.A.: Fungi associated with bovine abortion in the northern plains states (USA). J Vet Diagn Invest 1992, 4, 181-185.

25. Lanyon S.R., Reichel M.P.: Bovine viral diarrhoea virus ('pestivirus') in Australia: to control or not to control? Aust Vet J 2014, 92, 277-282.

26. Lucchese L., Benkirane A., Hakimi I., El Idrissi A., Natale A.: Seroprevalence study of the main causes of abortion in dairy cattle in Morocco. Vet Ital 2016, 52, 13-19.

27. Miller R., Nakavuma J.L., Ssajjakambwe P., Vudriko P., Musisi N., Kaneene J.B.: The prevalence of brucellosis in cattle, goats and humans in rural Uganda: a comparative study. Transbound Emerg Dis 2016, 63, 197-210.

28. Nielsen L.R.: Review of pathogenesis and diagnostic methods of immediate relevance for epidemiology and control of Salmonella Dublin in cattle. Vet Microbiol 2013, 162, 1-9.

29. OIE, World Organization for Animal Health. Chapter 2.1.4, Brucellosis. In: Manual of diagnostic tests and vaccines for terrestrial animals. Paris, 2017. pp. 44. http:/www.oie.int/en/ international-standard-setting/terrestrial-manual/access-online/. 
30. Olsen S.C., Palmer M. V.: Advancement of knowledge of Brucella over the past 50 years. Vet Pathol 2014, 51, 1076-1089.

31. Pawaiya R.V.S., Gupta V.K.: A review on Schmallenberg virus infection: a newly emerging disease of cattle, sheep and goats. Veterinarni Med 2013, 58, 516-526.

32. Sanhueza J.M., Heuer C., West D.: Contribution of Leptospira, Neospora caninum and bovine viral diarrhea virus to fetal loss of beef cattle in New Zealand. Prev Vet Med 2013,112, 90-98.

33. Smith C.R., Ketterer P.J., McGowan M.R., Corney B.G.: A review of laboratory techniques and their use in the diagnosis of Leptospira interrogans serovar hardjo infection in cattle. Aust Vet J 1994, 71, 290-294.

34. Straub O.C.: BHV1 infections: relevance and spread in Europe. Comp Immunol Microbiol Infect Dis 1991, 14, 175-186.

35. Talafha A.Q., Ababneh M.M., Ababneh M.M., Al-Majali A.M.: Prevalence and risk factors associated with Chlamydophila abortus infection in dairy herds in Jordan. Trop Anim Health Prod 2012, 44, 841-846.
36. Thrusfield M.: Veterinary epidemiology. ButterworthHeinemann Ltd, Oxford, UK, 1991.

37. Truyers I., Luke T., Wilson D., Sargison N.: Diagnosis and management of venereal campylobacteriosis in beef cattle. BMC Vet Res 2014, 27, 10-280.

38. Yang N., Cui X., Qian W., Yu S., Liu Q.: Survey of nine abortifacient infectious agents in aborted bovine fetuses from dairy farms in Beijing, China, by PCR. Acta Vet Hung 2012, 60, 83-92.

39. Yildiz K., Kul O., Babur C., Kil ic S., Gazyagci A.N., Celebi B., Gurcan I.S.: Seroprevalence of Neospora caninum in dairy cattle ranches with high abortion rate: special emphasis to serologic coexistence with Toxoplasma gondii, Brucella abortus and Listeria monocytogenes. Vet Parasitol 2009, 14, 306-310.

40. Zhai L., Kong X., Lu Z., Lv F., Zhang C., Bie X.: Detection of Salmonella enterica serovar Dublin by polymerase chain reaction in multiplex format. J Microbiol Methods 2014, 100, 52-57. 